Paedagogia Christiana

I/27 (201 I) - ISSN 1505-6872

Magdalena Kaczorowska*

Toruń

\title{
Życie i śmierć z perspektywy interdyscyplinarnej, Kraków, 22-23.02.2010 roku
}

Życie i śmierć z perspektywy interdyscyplinarnej to tytuł 13. Międzynarodowego Kongresu Polskiego Towarzystwa Neuropsychologicznego, a jednocześnie 2. Międzynarodowej Konferencji Pedagogiczno-Pychologicznej, które odbyły się w dniach 22-23.02.2010 roku w Krakowie. Miejscem obrad była Krakowska Akademia im. Andrzeja Frycza Modrzewskiego. Organizatorami wydarzenia były: Polskie Towarzystwo Neuropsychologiczne, Wydział Psychologii i Nauk o Rodzinie Krakowskiej Akademii im. Andrzeja Frycza Modrzewskiego oraz Katedra Pedagogiki Specjalnej WSFP „Ignatianum".

Program konferencji na pierwszy dzień podzielony został na cztery sesje plenarne, zatytułowane kolejno: Na granicy życia i śmierci, Eros $i$ Tanatos, Neuropsychologia oraz Neurodegeneracja. Na ten dzien program przewidywał między innymi następujące referaty: Zwtoki jako przedmiot szacunku i czci (autor: Józef Bremer), Nawet w śmierci jest życie - egzystencjalny wymiar śmierci (Grażyna Kwiatkowska), Czy człowiek może stać się Bogiem? Filozoficzne, psychologiczne, teologiczne i inne aspekty teorii przebóstwienia (Tomasz Niemirowski), Komórki nerwowe z krwi pepowinowej w perspektywie terapeutycznej (Krystyna Domańska-Janik), Neuropsychologiczne aspekty depresji (Andrzej Mirski, Natalia Mirska), Obraz wtasnej choroby a lęki i objawy depresyjne u osób z dysfunkcjami mózgu o etiologii naczyniowej (Łucja Domańska, Ewa Zawadzka).

* Magdalena Kaczorowska, studentka drugiego roku studiów uzupełniających na kierunku pedagogika, na Uniwersytecie Mikołaja Kopernika w Toruniu. 
Kolejny dzień konferencji podzielony został na następujące sesje plenarne: Neuropsychologia sqdowa, Rehabilitacja neuropsychologiczna, Spoteczny aspekt życia i śmierci oraz Dzieci i młodzież a życie i śmierć. Program przewidywał między innymi referaty: Życie - gniew - śmierć. Profilowanie gniewu w reklamach społecznych (Iwona Nowakowska-Kempna), Neuropsychologiczny, prawny i filozoficzny wymiar zycia i śmierci pacjenta po przebytym tętniaku mózgu (Marian Ledwoch, Kazimierz Hubert Konarzewski, Małgorzata Konarzewska), Odtwarzanie twarzy i mowy dziecka $z$ wadq twarzoczaszki jako szansa na pomyślne życie w spoteczeństwie (Danuta Pluta-Wojciechowska), Postawy wobec śmierci w kontekście zachowania autodestruktywnego (Barbara Pilecka), Autorska diagnostyka i metoda rozwoju kreatywnego potencjatu w stosowanej akmeologii (Natalia Wiszniakowa-Zelinskiy), Matka czy terapeutka? Dylemat roli i wybory życiowe podejmowane przez matki dzieci z uszkodzonym stuchem (Jolanta Baran), Dziecko a śmierć. Sposoby ujmowania problemu we współczesnej literaturze dla najmłodszych (Krystyna Zabawa), Rola rozwoju odruchów wczesnodziecięcych w procesie uczenia się (Celestyna Grzywniak).

Bez wątpienia każdemu z poruszonych problemów należy poświęcić więcej uwagi, jednakże nie sposób opisać w tym miejscu wszystkie z zaprezentowanych referatów, dlatego też w niniejszym sprawozdaniu pragnę opisać jedynie trzy wystapienia.

Jednym z nich jest referat zatytułowany Postawy wobec śmierci w kontekście zachowania autodestruktywnego. Barbara Pilecka, powtarzając za takimi specjalistami jak Elizabeth Kübler-Ross czy Zygmunt Freud, przywołała postawy, jakie ludzie najczęściej przejawiają wobec śmierci - żaden człowiek podświadomie jej nie przyjmuje, to inni zawsze umierają, nie my. Autorka zaprezentowała różne teorie niepokoju przed śmiercią. Jedną z nich była teoria Irvina Yaloma, mówiąca o niepokoju odgrywającym centralną rolę w życiu, a także o tym, jak istotne jest uświadomienie sobie własnej śmiertelności, chociaż może stanowić to przerażający cios, ponieważ ludzie boją się bólu, rozstania z bliskimi, oceny Boga, a także tego, czy coś ich później czeka. W wystapieniu poruszona została także niezwykle ważna kwestia, jaką jest stosunek człowieka do śmierci. Autorka skupiła się głównie na postawach samobójców, które opisać można jako ambiwalentne. $Z$ jednej bowiem strony chcą oni odebrać sobie życie, by doznać ulgi od cierpienia i uwolnić się od problemów, z którymi nie potrafią sobie poradzić, ale paradoksalnie istnieje też w nich pragnienie życia. Wnioski, jakie płyną z wystąpienia, są następujące: by ustrzec się przed sytuacja, gdy ludzie traktować zaczną śmierć jako jedyne wyjście i jedyną możliwość rozwiązania swoich kłopotów, potrzebne jest kształtowanie właściwej wobec niej postawy. Korzyścią płynącą z prawidłowo uformowanego stosunku do śmierci jest życie 
„W pełni”, afirmacja i docenienie własnego życia oraz świadomość, że nie ma problemów, których nie dałoby się rozwiązać, zawsze bowiem istnieje iskierka nadziei.

Matka czy terapeutka? Dylemat roli $i$ wybory życiowe podejmowane przez matki dzieci z uszkodzonym stuchem to kolejny referat warty omówienia. W trakcie wystąpienia autorka zawęziła swój temat, skupiając się tylko na dzieciach niesłyszących. Jolanta Baran mówiła początkowo o uczuciach towarzyszących matce, która dowiaduje się, że jej dziecko nie będzie słyszeć. Emocje, jakich w takiej chwili doświadcza kobieta, to żałoba, chroniczny ból, poczucie zranionego macierzyństwa, obniżenie jakości życia, stres, a także zespół wypalenia. Współcześnie pojawia się także pojęcie syndromu „niepełnosprawnego macierzyństwa” na określenie tego, z czym matka będzie musiała się zmierzyć i sobie poradzić. Najczęściej pojawiające się strategie radzenia sobie $\mathrm{z}$ wyzwaniem, jakim jest wychowanie dziecka niesłyszącego, jest jego izolacja, normalizacja życia oraz szczególne zaangażowanie się matki. Obserwować można dwie tendencje: dominująca rola matki, gdzie kobiety niejako zapominają o problemie i skupiają się wyłącznie na wychowaniu dziecka oraz dominująca rola terapeutki, gdzie kobieta staje się dla dziecka jedynym lekarzem i ,terapeutą". Wartym podkreślenia jest fakt, iż w obliczu sytuacji, gdy w rodzinie pojawia się dziecko niesłyszące, nic nie jest istotne - ważne jest tylko owo dziecko, któremu trzeba pomóc i wszystko trzeba mu podporządkować. Niejako podsumowując swoje wystąpienie, autorka powiedziała, iż czynnikiem zapewniającym brak problemów w akceptacji dziecka głuchego jest wzajemna miłość matki i ojca takiego dziecka.

Istotny problem został poruszony także w referacie Krystyny Zabawy pod tytułem: Dziecko a śmierć. Sposoby ujmowania problemu we wspótczesnej literaturze dla najmłodszych. Autorka poświęciła uwagę literaturze dziecięcej, poruszającej problem śmierci. Podkreśliła ona, iż śmierć jest także częścią życia i należy o niej rozmawiać, by - paradoksalnie - być bliżej życia, a zadaniem rodziców jest nauczenie się szczerości w rozmowach $\mathrm{z}$ dziećmi na ten bolesny temat, gdyż jednym z następstw niespójności wyjaśnień może być u dzieci histeria (jak zostało to ukazane w jednej z bajek). Krystyna Zabawa opisywała wybrane pozycje literaturowe, między innymi O mamie, która zagderała się na śmierć, Pewnej wrześniowej niedzieli, Mała ksiażka o śmierci. Przykładowe i istotne wypowiedzi, które się w nich pojawiły, były następujące: „To życie decyduje. Ono jest silniejsze ode mnie” (wypowiedź Śmierci), „Ale takie jest życie” (w trakcie śmierci jednego z bohaterów bajki). W tych prostych zdaniach ujęta została cała istota tego, czego rodzice powinni uczyć najmłodszych - śmierć jest czymś naturalnym, taki jest porządek życia, ale też tego, że owo życie jest niezwykłe i piękne. Baj- 
ki te pozostawiają bardzo ważne przesłanie - zmarli żyją w naszych wspomnieniach i sercach, i takiej postawy powinny być uczone dzieci. Autorka referatu nazwała te książki all-ages literature - przeznaczone pozornie dla dzieci, lecz tak naprawdę dorośli również mogą się z nich uczyć i odnaleźć przesłanie dla siebie.

Konferencja obfitowała w referaty (niestety nie wszystkie z zaplanowanych wystąpień odbyły się) poruszające różnego rodzaju problemy, z którymi pedagodzy, neuropsycholodzy, czy też ludzie niezwiązani z tymi dziedzinami coraz częściej się spotykają. Moim zdaniem, takie obrady powinny mieć miejsce jak najczęściej, gdyż mówiono tu o zagadnieniach stosunkowo nowych i nierozpowszechnionych (takich jak na przykład akmeologia), poruszono także tematy, którym wciąż poświęca się niedostatecznie dużo uwagi oraz podjęto próbę przełamywania społecznego tabu (na przykład, czy powinniśmy rozmawiać z dziećmi o śmierci i w jaki sposób to czynić). Konferencje takie są ogromną szansą na ciagge poszerzanie i pogłębianie wiedzy z dziedzin neuropsychologii, a także pedagogiki. Z ogromną radością przyjęłam więc wiadomość organizatorów o planowaniu kolejnej konferencji. 